\title{
PEMETAAN RISIKO KECELAKAAN LALU LINTAS DI RUAS JALAN TOL CIPULARANG
}

\author{
Deni Setiawan $^{(1)}$, Mayani Asima ${ }^{(2)}$ \\ ${ }^{(1)}$ Dosen Program Studi S-1 Teknik Sipil, Fakultas Teknik, Universitas Kristen Maranatha \\ ${ }^{(2)}$ Alumni Program Studi S-1 Teknik Sipil, Fakultas Teknik, Universitas Kristen Maranatha \\ Jalan Prof. Drg. Suria Sumantri No. 65, Bandung 40164 \\ e-mail: den9851@yahoo.com
}

\begin{abstract}
ABSTRAK
Salah satu tol yang tercatat rawan kecelakaan oleh Badan Pengusaha Jalan Tol (BPJT) Kota Bandung adalah Tol Cipularang. Mulai dari kecelakaan lalu lintas ringan yang tidak menimbulkan korban jiwa hingga kecelakaan lalu lintas berat yang menelan korban jiwa. Jumlah korban jiwa yang diakibatkan karena kecelakaan lalu lintas di Tol Cipularang akhir-akhir ini menjadi perhatian khusus bagi pengelola jalan tol dan masyarakat. Jasamarga Tbk mencatat korban jiwa dari kecelakaan lalu lintas pada Tahun 2014 hingga 2018 sebanyak 6.303 korban jiwa, sebanyak 1.261 korban per tahun dan sebanyak 106 setiap bulannya, berarti dapat dikatakan bahwa Tol Cipularang menelan 4 korban jiwa setiap harinya.Penelitian ini bertujuan untuk menganalisis faktor risiko kecelakaan lalu lintas dan melakukan pemetaan risiko (risk mapping) di ruas jalan Tol Cipularang yang menelan korban jiwa terbanyak dari Tahun 2014 hingga Tahun 2018. Hasil dari penelitian ini menunjukan bahwa risiko kecelakaan lalu lintas tertinggi terjadi pada Tahun 2014 dengan kategori risiko sangat berbahaya. Untuk pemetaan ruas jalan tol ditemukan bahwa titik paling rawan kecelakaan lalu lintas di Tol Cipularang berada di ruas Padalarang Barat KM.84-KM.120 Ram Jati Luhur. Sedangkan faktor dari kecelakaan lalu lintas paling dominan disebabkan oleh faktor manusia yaitu: kurang antisipasi dan mengantuk, yang kedua disebabkan oleh faktor kendaraan yaitu ban pecah, slip dan kerusakan mekanis.
\end{abstract}

Kata kunci: Cipularang kecelakaan, lalu lintas, risiko

\section{ABSTRACT}

One of the toll roads recorded as prone to accidents by the Toll Road Entrepreneurship Agency (BPJT) in Bandung City is the Cipularang Toll Road Section. Starting from minor traffic accidents that do not cause casualties to heavy traffic accidents that cost lives. The number of casualties caused by traffic accidents in Cipularang Toll Road has recently been of particular concern to toll road managers and the community. Jasamarga Tbk recorded 6,303 casualties from traffic accidents in 2014 to 2018, 1,261 victims per year and 106 every month, meaning that it can be said that the Cipularang toll road claimed 4 lives every day. This study aims to analyze risk factors traffic accidents and risk mapping on the Cipularang Toll Road which claimed the most fatalities from 2014 to 2018. The results of this study indicate that the highest risk of traffic accidents occurred in 2014 with a very dangerous risk category. For the mapping of the toll road, it was found that the most vulnerable points to traffic accidents at the Cipularang Toll Road were at the Padalarang Barat toll road KM. 84-KM. 120 Ram Jati Luhur. While the factors of traffic accidents are predominantly caused by human factors, namely: lack of anticipation and drowsiness, the second is caused by vehicle factors such as broken tires, slips and mechanical damage.

Keywords:PS Ball, Reinforced Concrete Beam, Monotonic Load, Cyclic Load, Performance. 


\section{PENDAHULUAN}

Kecelakaan lalu lintas pada umumnya timbul karena adanya interaksi antara eksposur dan risiko yaitu: kecelakaan yang terjadi karena kondisi arus lalu lintas yang padat atau pun yang lengang, kecelakaan yang terjadi akibat dari faktor manusia itu sendiri mencapai 95\% kecelakaan dan faktor manusia juga adalah faktor tunggal mencapai 65\% kecelakaan yang terjadi (Grime, 1987). Data WHO 2014 menyebutkan bahwa di indonesia tercatat jumlah korban jiwa kecelakaan lalu lintas mencapai angka rata-rata 1,2 juta jiwa orang meninggal dunia dan 50 juta lainnya mengalami luka-luka. Sementara itu angka kematian kecelakaan lalu lintas pada ruas jalan tol di Indonesia tercatat sebanyak 56\% dan belum terhitung korban luka lainnya (Adelaide, 2012). Tol Cipularang termasuk jalan tol yang risiko kecelakaan paling tinggi di Kota Bandung.

Tol Cipularang adalah salah satu jalan tol di Indonesia yang menghubungkan Kabupaten Purwakarta dan Bandung. Tol ini membentang dari Cikampek-Purwakarta sampai Padalarang. Tol Cipularang merupakan salah satu ruas jalan tol dengan angka kecelakaan yang cukup tinggi dibandingkan ruas tol lainnya. Pada penelitian sebelumnya angka kecelakaan di ruas jalan tol Cipularang mencapai 30 orang meninggal dunia dan 58 orang luka-luka, sedangkan pada Tahun 2018 angka kecelakaan meninggal sebanyak 73 orang dan 123 orang luka-luka atau sekitar 3 orang meninggal setiap 2 minggu yang melewati jalan tol Cipularang, dan diprediksi jumlah korban masih akan bertambah pada bulan Desember mendatang (Rahkmat, dkk, 2018). Tujuan penelitian ini adalah pemetaan risiko kecelakaan lalu lintas pada ruas Tol Cipularang

\section{STUDI PUSTAKA}

\subsection{Faktor Penyebab Kecelakaan Lalu Lintas}

Insiden kecelakaan lalu lintas yang terjadi dilapangan seringkali tidak dapat diketahui kapan akan terjadi dan dimana kecelakaan tersebut akan terjadi, biasanya kecalakaan lalu lintas dapat mengakibatkan kerugian material, korban manusia baik itu korban meninggal dunia, korban luka ringan dan korban luka berat (PP 43/93 Pasal 93).

Pada awalnya kecelakaan lalu lintas terjadi karena penyebab manusia saja atau bersifat monokausal. Kemudian seiring perkembangan jaman faktor penyebab kecelakaan semakin banyak diantaranya ada faktor manusia, faktor kendaraan, dan faktor lingkungan. (Austroads, 2002). Salah satu penyebab kecelakaan tertinggi disebabkan oleh manusia sebagai pengguna jalan. Pejalan kaki juga adalah pengguna jalan yang terkadang menjadi korban dari kecelakaan lalu lintas, hal tersebut menjadi perhatian yang khusus dari pengelola jalan tol maupun jalan umum. (Dephub, 2006). Faktor fisiologi dan psikologis 
manusia juga adalah salah satu yang mempengaruhi terjadinya kecelakaan. Faktor fisiologis dan psikologis dapat dilihat pada Tabel 2.1.

Tabel 2.1 Faktor Fisiologis dan Psikologis Manusia

\begin{tabular}{|c|c|}
\hline Faktor Fisiologis & Faktor Psikologis \\
\hline Faktor sistem syaraf & Dorongan \\
\hline Faktor penglihatan & Intelegensia \\
\hline Faktor pengendara & Pelajaran dan pengalaman \\
\hline Faktor perasaan & Emosional \\
\hline Indera sentuhan dan penciuman & Sikap dewasa \\
\hline Faktor fisiologis tubuh & Kebiasaan setiap hari \\
\hline
\end{tabular}

\section{Sumber: Adelaide, 2011}

Kecelakaan yang disebabkan oleh kendaraan lebih sedikit dibandingkan dengan faktor manusia. Akan tetapi faktor kendaraan memiliki aturan perundang-undangan yang membatasi kendaraan dari segi, berat kendaraan, ukuran kendaraan, penerang kendaraan, persyaratan rem dan lain-lain. Kecelakaan yang disebabkan oleh faktor kendaraan adalah rem blong, ban pecah, kerusakan mesin dan lain sebagainya. Akan tetapi kecelakaan dapat dihindari apa bila kendaraan yang digunakan dilakukan pengecekan terlebih dahulu. Kendaraan yang digunakan di jalan raya harus sudah melewati tahap sertifikasi yang diedarkan oleh metri perhubungan setempat (Adelaide, 2011). Keputusan Menteri Perhubungan Nomor 81 Tahun 1993 Tentang Uji Kelayakan Tipe Kendaraan Bermotor, antara lain: menjaga lingkungan dari kemungkinan yang diakibatkan oleh pengguna kendaraan bermotor di jalan untuk menghindari mengurangi risiko terjadinya kecelakaan,

Faktor jalan dan lingkungan termasuk penyebab kecelakaan lalu lintas diruas jalan tol, faktor jalan juga sangat berpengaruh terhadap kendaraan yang dikendaraai. Selain itu faktor gemometrik jalan harus benar-benar diperhatikan untuk menghindari kecelakaan lalu lintas. Ada empat faktor yang mempengaruhi kelakuan manusia sebagai faktor penyebab terjadinya kecelakaan antara lain:

1. keadaan tanah disekitar lokasi atau jalan, kondisi yang ramai, kondisi sepi yang berakibat pengemudi menjadi lalai dan lengah;

2. pengaruh kondisi alam seperti cuaca buruk hujan, yang membuat jalan jadi licin sehingga kendaraan yang dikendarai tergelincir;

3. alat penunjang keselamatan di jalan tol seperti marka jalan, rambu lalu lintas, dan fasilitas lainnya yang menunjang keselamatan pengguna jalan tol; 
4. suasana lalu lintas di jalan, baik itu macet lengang dan faktor lain yang memberi dampak terhadap kecelakaan.

\section{DESAIN PENELITIAN}

Desain penelitian yang diterapkan dalam penelitian ini adalah metode penelitian deskriptif, Pengertian metode deskriptif menurut Nazir yaitu dilakukan dengan cara kualitatif atau mencari teori dari beberapa sumber terpercaya. Cirikhas lain dari metode dilakukan dengan observasi atau terjun langsung di lapangan (Ardianto, 2011).

Metode deskriptif dikelolah untuk memperoleh suatu gambaran mengenai peristiwa yang ada saat ini di lokasi yang diteliti atau yang dijadikan objek penelitian untuk memperoleh suatu permasalahan yang akan dilakukan analisis atau identifikasi. Biasanya penelitian dengan metode deskriptif dilakukan apa bila sumber yang akan diteliti menarik dan dapat digambarkan secara faktual dan cermat. Tahapan penelitian ini terdiri dari:

\section{Studi Literatur}

Tinjauan literatur bertujuan untuk mengumpulkan informasi tertulis mengenai segala sesuatu yang terjadi dilapangan agar dapat disimpulkan bagaimana cara yang harus dilakukan untuk mengatasi atau mengurangi risiko kecelakaan lalu lintas dijalan tol Cipularang kota Bandung.

2. Pengumpulan Data

Teknik pengumpulan data yang akan dilakukan adalah dengan cara: pengumpulan data sekunder berupa tinjauan literatur yang diperoleh dari buku- buku, referensi, jurnal-jurnal serta penelitian yang lalu. Data sekunder pada penelitian ini juga mengobservasi dan meneliti keadaan lapangan yang ada dijalan tol Cipularang serta mengambil foto-foto di lapangan.

3. Mengidentifikasi Risiko

Mengidentifikasi risiko adalah usaha yang harus dilakukan untuk dapat berjalan dengan terstruktur, komprehensif maupun sistematis, hal tersebut sangat penting karena risiko potensial tidak diidentifikasi pada tahap ini dikarenakan termasuk dalam analisis lanjut. Kegiatan mencari atau mengumpulkan suatu masalah harus dilakukan dengan mecakup semua aspek risiko yang baik atau risiko yang sangan buruk. Cara maupun teknik yang dapat digunakan untuk identifikasi risiko adalah: metode aproksimasi, yaitu cara untuk mengetahui probabilitas dan dampak risiko dengan cara menanyakan kira-kira berapa probabilitas dan dampak dari suatu risiko kepada orang lain (ahli).

Pemetaan Risiko Kecelakaan Lalu Lintas Di Ruas Jalan Tol Cipularang 
4. Menganalisis risiko

Manfaat dari analisis risiko yaitu untuk mengkaji dan memisahkan risiko yang terjadi baik itu risiko sedang, risiko berat, dan risiko ringan. Analisis risiko tersebut dilakukan berdasarkan berbagai pertimbangan seperti konsekuensi yang ada dan bisa saja dari konsekuensi kemungkinan terjadinya untuk ditelaah. Kegiatan analisis tersebut berupa menyatuhkan beberapa keputusan ataupun kejadian yang bisa saja terjadi tapi dalam ruang lingkup dari pengendalian yang sudah ada sebelumnya. Biasanya untuk melakukan suatu analisis harus memiliki beberapa masalah yang diteliti bisa juga informasi didapat dari data yang tersedia contoh melanjutkan apa yang menjadi bahan pemikiran orang lain, kejadian yang terjadi disebuah perusahaan, mealalui kehidupan sehari-hari, bisa juga berdasarkan dari uji coba dan pendapat para pakar dan lain-lain. Untuk kegiatan menganalisis risiko ada beberapa metode yang harus kita gunakan yaitu: bersifat kualitatif, penilaian semi kuantitatif, kuantitatif dari gabungan beberapa kegiatan yang ada atau dari gabungan yang ada (Wiryani, dkk, 2013).

a. Penilaian risiko dengan analisis kualitatif

b. penilaian risiko dengan analisis semi kuantitatif

Tabel 3.1 Penilaian Tingkat Risiko

\begin{tabular}{|l|c|c|}
\hline \multicolumn{1}{|c|}{$\begin{array}{c}\text { Hasil Evakuasi Korban Kecelakaan Berkendara } \\
\text { di Jalan Tol }\end{array}$} & Nilai Kualitatif & $\begin{array}{c}\text { Nilai } \\
\text { Kuantitatif }\end{array}$ \\
\hline Korban hanya mengalami kerugian material & Amat Ringan & 1 \\
\hline Korban mengalami luka ringan (lecet) & Ringan & 10 \\
\hline $\begin{array}{l}\text { Korban mengalami luka berat tapi tidak sampai cacat } \\
\text { atau kerugian material lain. }\end{array}$ & Sedang & 40 \\
\hline $\begin{array}{l}\text { Korban mengalami luka berat atau cacat permanen } \\
\text { hingga kerugian material }\end{array}$ & Berat & 70 \\
\hline $\begin{array}{l}\text { Korban meningga dunia setelah kecelakaan terjadi } \\
\text { dan kerugian material. }\end{array}$ & Amat Berat & 100 \\
\hline
\end{tabular}

Sumber: Wiranto, dkk., 2014

Penilaian tingkat risiko dari persamaan diatas untuk mentukan tingkat risiko hasil dari perkalian dapat dilihat persamaan 3.1 sedangkan nilai risiko dan kategori risiko dapat dibagi dalam beberapa kategori seperti pada Tabel 3.2. Evaluasi tingkat risiko dapat dilihat pada Tabel 3.3.

Level of risk $=$ consequences $x$ likelihood $x$ exposure 
Tabel 3.2 Kategori Risiko

\begin{tabular}{|l|l|l|}
\hline \multicolumn{1}{|c|}{$\begin{array}{c}\text { Nilai } \\
\text { Risiko }\end{array}$} & Kategori Risiko & \multicolumn{1}{c|}{ Tingkat Kepentingan Penanganan } \\
\hline$<125$ & $\begin{array}{l}\text { Tidak Berbahaya } \\
\text { (TB) }\end{array}$ & $\begin{array}{l}\text { Perlu dilakukan pengawasan lebih lanjut dititik rawan } \\
\text { kecelakaan. }\end{array}$ \\
\hline $125-250$ & $\begin{array}{l}\text { Cukup Berbahaya } \\
\text { (CB) }\end{array}$ & $\begin{array}{l}\text { Dilakukan penanganan atau inspeksi keselamatan } \\
\text { jalan dititik rawan kecelakaan. }\end{array}$ \\
\hline $250-375$ & Berbahaya (B) & $\begin{array}{l}\text { Apabila keselamatan jalan sudah disetujui kemudian } \\
\text { penganan dilakukan terjadwal maksimal dua bulan } \\
\text { sekali. }\end{array}$ \\
\hline$>375$ & $\begin{array}{l}\text { Sangat Berbahaya } \\
\text { (SB) }\end{array}$ & $\begin{array}{l}\text { Penanganan dilakukan secara total akan tetapi setelah } \\
\text { uadit jalan disetujui minimal dalam 2 Minggu. }\end{array}$ \\
\hline
\end{tabular}

Sumber: Wiranto, dkk., 2014

Tabel 3.3 Evaluasi Tingkat Risiko

\begin{tabular}{|l|c|c|}
\hline \multicolumn{1}{|c|}{$\begin{array}{c}\text { Hasil Ukur Dimensi dan Tata Letak } \\
\text { Bagian Infrastruktur Jalan Tol }\end{array}$} & Nilai Kualitatif & $\begin{array}{c}\text { Nilai } \\
\text { Kuantitatif }\end{array}$ \\
\hline $\begin{array}{l}\text { Kejadian yang terdapat di lapangan }>10 \% \\
\text { dari standar teknisnya. }\end{array}$ & $\begin{array}{c}\text { Tidak pernah terjadi } \\
\text { kecelakaan }\end{array}$ & 1 \\
\hline $\begin{array}{l}\text { Kejadian dilapangan antara } 10 \%-40 \% \\
\text { terhadap standar teknisnya. }\end{array}$ & $\begin{array}{c}\text { Terjadi kecelakaan } \\
\text { sampai } 5 \text { kali pertahun }\end{array}$ & 2 \\
\hline $\begin{array}{l}\text { Kejadian di lapangan antara } 40 \%-70 \% \\
\text { terhadap standar teknisnya }\end{array}$ & $\begin{array}{c}\text { Terjadi kecelakaan 5 - } \\
10 \text { kali pertahun }\end{array}$ & 4 \\
\hline $\begin{array}{l}\text { Perbedaan yang terukur di lapangan } \\
\text { antara } 70 \% \text { sampai } 100 \% \text { terhadap standar } \\
\text { teknisnya }\end{array}$ & $\begin{array}{c}\text { Terjadi kecelakaan } 10- \\
15 \text { kali pertahun }\end{array}$ \\
\hline $\begin{array}{l}\text { Kejadian di lapangan mencapai } 100 \% \\
\text { terhadap standar teknisnya. }\end{array}$ & $\begin{array}{c}\text { Terjadi kecelakaan lebih } \\
\text { dari } 15 \text { kali pertahun }\end{array}$ & 5 \\
\hline
\end{tabular}

Sumber: Wiranto, dkk., 2014

Penilaian terhadap seberapa besar risiko yang ditimbulkan dari kegagalan dan kelalaian sudah dikategorikan berdasarkan parameter ukur matriks risiko untuk menentukan kategori suatu risiko apakah itu rendah, sedang, tinggi ataupun juga extrim dapat menggunakan metode matriks risiko seperti pada Tabel 3.4

Pemetaan Risiko Kecelakaan Lalu Lintas Di Ruas Jalan Tol Cipularang 
Tabel 3.4 Matriks Risiko

\begin{tabular}{|c|c|c|c|c|c|}
\hline \multirow[b]{2}{*}{ Frekuensi } & \multicolumn{5}{|c|}{ Dampak } \\
\hline & $\begin{array}{c}\text { Tidak } \\
\text { Signifikan } \\
\text { (1) }\end{array}$ & Kecil (2) & $\begin{array}{l}\text { Sedang } \\
\text { (3) }\end{array}$ & Besar (4) & Ekstim (5) \\
\hline Jarang (1) & $\mathrm{L}(1 \mathrm{x} 1)$ & $\mathrm{L}(1 \times 2)$ & $\mathrm{L}(1 \mathrm{x} 3)$ & $\mathrm{L}(1 \times 4)$ & $M(1 \times 5)$ \\
\hline $\begin{array}{l}\text { Kemungkinan } \\
\text { sedang (2) }\end{array}$ & $\mathrm{L}(2 \times 1)$ & $\mathrm{L}(2 \times 2)$ & $M(2 \times 3)$ & $M(2 \times 4)$ & $\mathrm{H}(2 \times 5)$ \\
\hline Sedang (3) & $\mathrm{L}(3 \times 1)$ & $M(3 \times 2)$ & $M(3 \times 3)$ & $\mathrm{H}(3 \mathrm{x} 4)$ & $\mathrm{H}(3 \times 5)$ \\
\hline Besar (4) & $\mathrm{L}(4 \mathrm{x} 1)$ & $M(4 \times 2)$ & $\mathrm{H}(4 \times 3)$ & $H(4 x 4)$ & $\mathrm{E}(4 \times 5)$ \\
\hline Pasti (5) & $M(5 \times 1)$ & $\mathrm{H}(5 \mathrm{x} 2)$ & $\mathrm{H}(5 \mathrm{x} 3)$ & $\mathrm{E}(5 \times 4)$ & E (5X5) \\
\hline
\end{tabular}

Sumber: Adzim, 2013

Keterangan Tabel:

Risiko extrim (E) adalah mempunya risiko tinggi, penanganan dilakukan segera mungkin, Risiko tinggi $(H)$ adalah risiko yang memerlukan perhatian khusus dari pihak yang bertanggung jawan terhadap kecelakaan lalu lintas, Risiko Sedang (M) yaitu risiko yang bertanggung adalah manajemen dan tindakan harus dilakukan secara spesifik. Risiko rendah (L) adalah risiko yang tingkat penangan dilakukan secara rutin sesuai prosedur.

\section{ANALISIS DATA DAN PEMBAHASAN}

\subsection{Data Kecelakaan Lalu Lintas di Jalan Tol Cipularang}

Kendaraan di jalan tol terdiri dari beberapa golongan, diantaranya adalah kendaraan golongan I yang terdiri dari jenis-jenis kendaraan seperti: Kendaraan jenis sedan, jeep, pick up, minibus, bus sedang, bus besar $>2$ AS dan bus besar -3 AS. Kendaraan golongan I tersbut dapat dilihat dengan jelas pada Tabel 4.1. Kendaraan golongan I tersebut juga di kategorikan sebagai frekuensi atau nilai probabilitas dari kejadian kecelakaan. Dapat dilihat pada Tabel 4.1.

Secara umum pembagian jenis kendaraan jalan tol diantaranya yaitu kendaraan golongan I dan kendaraan golongan II yang terdiri dari kendaraan jenis truck kecil, truck besar $>2$ AS. Untuk nilai probabilitas suatu matriks kendaraan golongan 2 termasuk dikategorikan 5, karena memiliki kejadian kecelakaan dari Tahun 2014 sampai 2018 lebih dari 100 kejadian kecelakaan. Jenis kendaraan golongan II dapat dilihat pada Tabel 4.2. 
Tabel 4.1 Jenis-Jenis Kendaraan Golongan I

\begin{tabular}{|l|c|c|c|c|c|}
\hline \multirow{2}{*}{$\begin{array}{c}\text { Kendaraan Golongan } \\
\text { I }\end{array}$} & $\mathbf{2 0 1 4}$ & $\mathbf{2 0 1 5}$ & $\mathbf{2 0 1 6}$ & $\mathbf{2 0 1 7}$ & $\mathbf{2 0 1 8}$ \\
\cline { 2 - 6 } & 112 & 43 & 50 & 111 & 50 \\
\hline Sedan & 28 & 28 & 29 & 55 & 42 \\
\hline Jeep & 114 & 62 & 68 & 74 & 50 \\
\hline Pick Up & 511 & 241 & 160 & 342 & 262 \\
\hline Minibus & 0 & 0 & 0 & 17 & 32 \\
\hline Bus Sedang & 141 & 23 & 50 & 11 & 80 \\
\hline Bus Besar > 2AS & 1 & 0 & 0 & 11 & 0 \\
\hline Bus Besar - 3AS & 907 & 397 & 357 & 621 & 516 \\
\hline Jumlah & \multicolumn{7}{|c|}{ Tahun } \\
\hline
\end{tabular}

Sumber: Jasamarga Tbk. Kota Bandung

Tabel 4.2 Jenis-jenis Kendaraan Golongan II

\begin{tabular}{|l|c|c|c|c|c|}
\hline \multirow{2}{*}{$\begin{array}{c}\text { Kendaraan Golongan } \\
\text { I }\end{array}$} & \multicolumn{5}{|c|}{ Tahun } \\
\cline { 2 - 6 } & $\mathbf{2 0 1 4}$ & $\mathbf{2 0 1 5}$ & $\mathbf{2 0 1 6}$ & $\mathbf{2 0 1 7}$ & $\mathbf{2 0 1 8}$ \\
\hline Truck Kecil & 240 & 138 & 178 & 164 & 94 \\
\hline Truck Besar > 2AS & 285 & 173 & 142 & 138 & 68 \\
\hline Frekuensi & 525 & 311 & 320 & 302 & 162 \\
\hline
\end{tabular}

Sumber: PT.Jasamarga Tbk Kota Bandung

Dampak kecelakaan lalu lintas di jalan tol cipulang mengakibatkan korban meninggal dunia, luka ringan, luka berat dan kerugian material yang ditanggung oleh pengemudi yang mengalami kecelakaan di jalan tol terstersebut. Jumlah korban dari kecelakaan tersebut merupakan suatu dampak dari kecelakaan yang terjadi dijalan tol Cipularang. Dapat dilihat dengan jelas pada Tabel 4.3.

Tabel 4.3 Jenis-Jenis Kecelakaan Lau Lintas Di Jalan Tol Cipularang

\begin{tabular}{|l|c|c|c|c|c|}
\hline \multirow{2}{*}{\begin{tabular}{c}
\multirow{2}{*}{$\begin{array}{c}\text { Jenis-Jenis } \\
\text { Kecelakaan }\end{array}$} \\
\cline { 2 - 6 }
\end{tabular}} & \multicolumn{5}{|c|}{ Dampak } \\
\cline { 2 - 6 } & $\mathbf{2 0 1 4}$ & $\mathbf{2 0 1 5}$ & $\mathbf{2 0 1 6}$ & $\mathbf{2 0 1 7}$ & $\mathbf{2 0 1 8}$ \\
\hline Luka Ringan & 1185 & 632 & 390 & 790 & 214 \\
\hline Luka Berat & 669 & 445 & 300 & 520 & 640 \\
\hline Meninggal Dunia & 116 & 109 & 26 & 170 & 97 \\
\hline Jumlah & 1970 & 1186 & 716 & 1480 & 951 \\
\hline
\end{tabular}

\section{Sumber: PT.Jasamarga Tbk Kota Bandung}




\subsection{Pemetaan Risiko Kecelakaan Lalu Lintas}

Pemetaan lokasi kecelakaan lalu lintas dilakukan dengan pengelompokan data perhari, perbulan kemudian dari data perbulan data dikelompokkan menjadi data pertahun, makan dari itu pemetaan lokasi kecelakaan lalu lintas paling rawan dapat diperoleh seperti pada Tabel 4.4 Dari tabel dibawah dapat dilihat kecelakaan paling tinggi terjadi diruas Jati Luhur Padalarang-Ram jati Luhur KM.84-KM.120. Pada Tahun 2014 tertinggi dari Tahun berikutnya dengan jumlah kecelakaan 372 kejadian, kemudian menurun hingga Tahun 2016 dan meningkat lagi hingga Tahun 2018 dengan jumlah kejadian hingga 255. Dapat dilihat pada Tabel 4.4.

Tabel 4.4 Ruas Jalan Tol Cipularang Tahun 2014-2018

\begin{tabular}{|c|c|c|c|c|c|}
\hline \multirow{2}{*}{ Ruas Jalan Tol } & 2014 & 2015 & 2016 & 2017 & 2018 \\
\hline & Jalur A & Jalur A & Jalur A & Jalur A & Jalur A \\
\hline $\begin{array}{l}\text { Kalihurip itc - Sadang } \\
\text { itc } \quad \text { KM.66+400- } \\
\text { KM.76+000 }\end{array}$ & 96 & 25 & 24 & 10 & 13 \\
\hline $\begin{array}{l}\text { Sadang itc }- \text { Jatiluhur } \\
\text { itc } \quad \text { KM.76+000- } \\
\text { KM.84+000 }\end{array}$ & 66 & 39 & 7 & 78 & 54 \\
\hline $\begin{array}{lr}\text { Jatiluhur } & \text { itc } \\
\text { Padalarang } & \text { Barat } \\
\text { KM. } 84+000- & \\
\text { KM.120+500 } & \text { Ram } \\
\text { Jatiluhur } & \\
\end{array}$ & 372 & 251 & 211 & 284 & 255 \\
\hline $\begin{array}{ll}\text { Padalarang } & \text { Barat } \\
\text { KM. } 120+500- & \\
\text { KM. } 122+400 & \end{array}$ & 24 & 16 & 28 & 0 & 6 \\
\hline Jumlah & 558 & 331 & 270 & 372 & 328 \\
\hline
\end{tabular}

Sumber: PT.Jasamarga Tbk. Kota Bandung

Untuk pemetaan lokasi titik rawan kecelakaan hanya dilakukan di jalur A, arah Bandung-Padalarang Barat, karena kecelakaan lalu lintas paling tinggi terjadi dijalur tersebut. Dari hasil Tabel 4.4 titik rawan kecelakaan lalu lintas berada di ruas Jatiluhur Padalarang Barat KM.84-KM.120 Ram Jatiluhur dengan jumlah kecelakaan pada Tahun 2014 sebanyak 372, Tahun 2015, sebanyak 251 kecelakaan, Tahun 2016 sebanyak 211 kecelakaan, Tahun 2017 sebanyak 284, kejadian kecelakaan dan Tahun 2018 sebanyak 255 jumlah kejadian kecelakaan. Hasil analisis tersebut diuraikan pada Tabel 4.5 dengan jumlah kecelakaan yang terjadi di Tol Cipularang berdasarkan kecekaan yang terjadi disetiap KM jalan tol Cipularang dari KM.83-KM.120 yang merupakan titik rawan 
kecelakaan berdasarkan hasil analisis Tabel 4.4. Untuk uruain kecelakaan per KM dapat dilihat pada Tabel 4.5.

Tabel 4.5 Tol Cipularang KM.83+100-KM.120+555

\begin{tabular}{|c|c|c|c|c|c|c|c|}
\hline \multirow{2}{*}{$\mathrm{KM}$} & \multicolumn{5}{|c|}{ TAHUN } & \multirow{2}{*}{ Jumlah } & \multirow{2}{*}{$\begin{array}{c}\text { Alinyemen } \\
\text { Jalan }\end{array}$} \\
\hline & 2014 & 2015 & 2016 & 2017 & 2018 & & \\
\hline $83-84$ & 11 & 0 & 0 & 0 & 11 & 22 & Lurus Turun \\
\hline $84-85$ & 11 & 0 & 0 & 6 & 13 & 30 & Lurus Turun \\
\hline $85-86$ & 24 & 0 & 18 & 12 & 10 & 64 & Lurus Turun \\
\hline $86-87$ & 27 & 16 & 20 & 13 & 0 & 76 & Lurus Turun \\
\hline $87-88$ & 23 & 0 & 4 & 2 & 0 & 29 & Lurus Naik \\
\hline $88-89$ & 9 & 13 & 0 & 12 & 6 & 40 & Lurus Naik \\
\hline $89-90$ & 9 & 6 & 0 & 0 & 12 & 27 & Lurus Naik \\
\hline $90-91$ & 4 & 7 & 13 & 13 & 13 & 50 & Nikung Naik \\
\hline $91-92$ & 36 & 59 & 40 & 31 & 31 & 197 & Nikung Naik \\
\hline $92-93$ & 67 & 33 & 50 & 33 & 22 & 205 & Nikung Naik \\
\hline $93-94$ & 19 & 3 & 9 & 0 & 0 & 31 & Nikung Naik \\
\hline $94-95$ & 2 & 0 & 0 & 0 & 0 & 2 & Nikung Datar \\
\hline $95-96$ & 0 & 0 & 0 & 0 & 0 & 0 & Nikung Datar \\
\hline $96-97$ & 11 & 5 & 3 & 0 & 12 & 31 & Nikung Datar \\
\hline $97-98$ & 22 & 16 & 9 & 18 & 11 & 76 & Nikung Datar \\
\hline $98-99$ & 11 & 3 & 6 & 0 & 0 & 20 & Lurus Turun \\
\hline $99-100$ & 20 & 0 & 20 & 4 & 5 & 49 & Lurus Turun \\
\hline $100-101$ & 18 & 0 & 6 & 40 & 0 & 64 & Lurus Turun \\
\hline $101-102$ & 9 & 6 & 13 & 11 & 0 & 39 & Lurus Turun \\
\hline $102-103$ & 8 & 0 & 11 & 0 & 2 & 21 & Lurus Naik \\
\hline $103-104$ & 0 & 12 & 0 & 9 & 15 & 36 & Lurus Naik \\
\hline $104-105$ & 24 & 0 & 2 & 0 & 0 & 26 & Lurus Naik \\
\hline $105-106$ & 2 & 0 & 0 & 0 & 0 & 2 & Lurus Datar \\
\hline $106-107$ & 1 & 8 & 0 & 0 & 0 & 9 & Lurus Datar \\
\hline $107-108$ & 5 & 0 & 6 & 9 & 0 & 20 & Lurus Datar \\
\hline $108-109$ & 4 & 0 & 5 & 0 & 9 & 18 & Lurus Datar \\
\hline $109-110$ & 10 & 0 & 0 & 0 & 0 & 10 & Lurus Datar \\
\hline $110-111$ & 26 & 0 & 11 & 0 & 0 & 37 & Lurus Datar \\
\hline $111-112$ & 42 & 13 & 16 & 0 & 0 & 71 & Lurus Datar \\
\hline $112-113$ & 5 & 9 & 0 & 0 & 0 & 14 & Lurus Datar \\
\hline $113-114$ & 21 & 0 & 0 & 0 & 2 & 23 & Lurus Datar \\
\hline $114-115$ & 15 & 8 & 0 & 0 & 0 & 23 & Lurus Naik \\
\hline $115-116$ & 16 & 8 & 3 & 22 & 4 & 53 & Lurus Naik \\
\hline $116-117$ & 25 & 14 & 9 & 0 & 0 & 48 & Lurus Naik \\
\hline
\end{tabular}


Tabel 4. 5 Tol Cipularang KM.83+100-KM.120+555 (Lanjutan)

\begin{tabular}{|c|c|c|c|c|c|c|c|}
\hline \multirow{2}{*}{$\mathrm{KM}$} & \multicolumn{5}{|c|}{ TAHUN } & \multirow{2}{*}{ Jumlah } & \multirow{2}{*}{$\begin{array}{c}\text { Alinyemen } \\
\text { Jalan }\end{array}$} \\
\hline & 2014 & 2015 & 2016 & 2017 & 2018 & & \\
\hline $117-118$ & 7 & 9 & 12 & 0 & 0 & 28 & Lurus Naik \\
\hline $118-119$ & 18 & 0 & 0 & 12 & 0 & 30 & Lurus Turun \\
\hline $119-120$ & 13 & 5 & 0 & 15 & 0 & 33 & Lurus Turun \\
\hline
\end{tabular}

Sumber: PT.Jasamarga Tbk. Kota Bandung

Dari hasil analisis pemetaan risiko kecelakaan lalu lintas pada Tabel 4.4 dan Tabel 4.5 diperoleh titik rawan kecelakaan lalu lintas di ruas jalan tol Jatiluhur Padalarang Barat KM.84+000+500 sampai KM.120 Ram Jati Luhur.

\subsection{Faktor Penyebab Terjadinya Kecelakaan Lalu Lintas}

Salah satu penyebab terjadinya kecelakaan lalu lintas adalah faktor manusia itu sendiri. Faktor dari manusia itu sendiri yaitu berupa, kurangnya antisipasi, lengah, mengantuk, mabuk, tidak tertib (jarak rapat). Pada Tabel 4.6 dengan periode data 20142018 dengan jumlah korban masih tergolong banyak dan berisiko tinggi. Terlihat bahwa berdasarkan data, penyebab dominan dari kelalaian manusia adalah kurangnya antisipasi dan mengantuk. Kelalaian tersebut sebenarnya bisa saja diantisipasi misalnya dengan melakukan pengecekan kondisi kesehatan terlebih dahulu sebelum mengemudi, makan secukupnya supaya tidak hilang konsentrasi saat mengemudi karena perut kosong, pergunakan bahu jalan untuk beristirahat sejenak untuk melepas lelah dan hal kecil lain yang dapat dilakukan dari diri sendiri untuk menghindari terjadinya kecelakaan.

Tabel 4.16 Faktor Manusia (Pengemudi)

\begin{tabular}{|l|c|c|c|c|c|}
\hline \multirow{2}{*}{ Faktor Penyebab Pengemudi } & \multicolumn{5}{|c|}{ Tahun } \\
\cline { 2 - 6 } & $\mathbf{2 0 1 4}$ & $\mathbf{2 0 1 5}$ & $\mathbf{2 0 1 6}$ & $\mathbf{2 0 1 7}$ & $\mathbf{2 0 1 8}$ \\
\hline Kurang Antisipasi & 832 & 328 & 528 & 0 & 0 \\
\hline Lengah & 24 & 4 & 4 & 0 & 0 \\
\hline Mengantuk & 800 & 464 & 304 & 0 & 0 \\
\hline Mabuk & 0 & 0 & 0 & 0 & 0 \\
\hline Tidak Tertib (Jarak Rapat) & 10 & 0 & 0 & 0 & 0 \\
\hline Jumlah & 1666 & 796 & 836 & 0 & 0 \\
\hline Sumber: PTasamy
\end{tabular}

Sumber: PT.Jasamarga Tbk. Kota Bandung

Pada Tahun 2014 korban jiwa akibat kurang antisipasi sebanyak 832 kejadian kecelakaan, kemudian pada tahun 2015 terjadi penurunan sebanyak 328 kejadian kecelakaan, kemudian pada Tahun 2016 dengan penyebab yang sama kejadian 
kecelakaan meningkat hingga 526 kejadian kecelakaan. Akan tetapi pada. Tahun 2017 hingga 2018 terlihat pada tabel korban jiwa sangat signifikan berkurang hingga tidak ada kejadian kecelakaan, sedangkan kejadian kecelakaan disebabkan karna mengantuk pada Tahun 2014 tertinggi sebanyak 800 kejadian kecelakaan. Pada Tahun 2015-2016 terjadi penurunan dari 464 kejadian kecelakaan menjadi 304 dan menurun signfikan hingga tidak ada korban jiwa sampai Tahun 2018.

Faktor kendaraan termasuk penyebab tertinggi kedua sesudah faktor manusia yang terjadi di tol Cipularang sepanjang Tahun 2014 hingga 2018, dan angka tertinggi dari faktor kendaraan itu sendiri adalah ban pecah, rem blong, slip, kerusakan mekanis, kendaraan berhenti, kerusakan mesin dan yang terendah adalah kerusakan dari mesin kendaraan. Data penyebab kecelakaan yang diakibatkan oleh factor kendaraan dapat dilihat pada Tabel 4.7 .

Tabel 4.7 Faktor Kendaraan

\begin{tabular}{|l|c|c|c|c|c|}
\hline Faktor Penyebab & \multicolumn{5}{|c|}{ Tahun } \\
\hline Kendaraan & $\mathbf{2 0 1 4}$ & $\mathbf{2 0 1 5}$ & $\mathbf{2 0 1 6}$ & $\mathbf{2 0 1 7}$ & $\mathbf{2 0 1 8}$ \\
\hline Ban Pecah & 236 & 128 & 46 & - & 0 \\
\hline Slip & 32 & 8 & 42 & - & 0 \\
\hline Rem Blong & 112 & 88 & 88 & - & 0 \\
\hline Kerusakan Mesin & 24 & 0 & 4 & - & 0 \\
\hline Kerusakan Mekanis & 42 & 10 & 0 & - & 0 \\
\hline Kendaraan Berhenti & 18 & 0 & 14 & - & 0 \\
\hline Jumlah & 478 & 268 & 218 & 0 & 0 \\
\hline
\end{tabular}

Sumber: PT.Jasamarga Tbk Kota Bandung

Pada tahun 2014 faktor kendaraan antara lain disebabkan oleh ban pecah, dengan kejadian kecelakaan sebanyak 410 Tahun 2014 tertinggi dan menurun hingga Tahun 2018. Rem blong 288 kejadian kecelakaan kemudian menurun hingga 2018. Slip hanya 82 kejadian kecelakaan, akan tetapi dari Tahun 2014 meningkat hingga Tahun 2016, kemudian terjadi perubahan signifikan hingga tidak adanya korban jiwa sampai 2018.

\section{SIMPULAN}

Berdasarkan hasil analisis, dapat disimpulkan bahwa pemetaan titik rawan risiko kecelakaan lalu lintas di jalan tol Cipularang berada di ruas Jatiluhur Padalarang barat KM.84-KM.120 Ram Jatiluhur dengan jumlah korban periode selama lima Tahun sebanyak 1.373 kejadian kecelakaan, dengan nilai risiko pada kendaraan golongan I dan golongan II Tahun 2014-2015 Sangat Berbahaya (SB), Tahun 2016-2018 tingkat risiko 
kecelakaan berkurang dengan kategori risko tidak berbahaya (TB) dan Berbahaya (B). Dari hasil analisis yang paling berpengaruh terhadap kecelakaan lalu lintas yaitu, pertama adalah faktor manusia yang disebabkan oleh kurang antisipasi sebanyak 1.688 kecelakaan, mengantuk 1.568 kecelakaan dan yang kedua adalah faktor kendaraan disebabkan oleh ban pecah sebanyak 410 dan rem blong sebanyak 288 kejadian kecelakaan. Berdasarkan hasil analisis terdapat bahwa kecelakaan terjadi di hari libur dan jam kerja pada waktu $00.00-06.00 \& 12.00-18.00$ kondisi cauaca cerah. Sedangkan untuk faktor kondisi jalan pada KM 90-93 kecelakaan terjadi karena kondisi jalan terdiri dari tikungan dan tanjakan.

\section{DAFTAR PUSTAKA}

1. Adelaide, 2011, Gambaran Faktor-Faktor Penyebab Kecelakaan Lalu Lintas di Jalan Tol Purbaleunyi. Skripsi, Depok.

2. Antoro, 2006, Analisis Hubungan Kecelakaan Dan V/C Rasion, Tesis, Pasca Sarjana, Universitas Diponegoro, Semarang.

3. Grime, 1987, Analisis Risiko Kecelakaan Lalu Lintas Berdasar Pengetahuan, Pengguna Jalur, dan Kecepatan Berkendara, Jurnal Berkala Epidemiologi, Universitas Airlangga, Surabaya.

4. Rakhmat, dkk, 2018, Pengembangan Model Prediksi Kecelakaan Lalu Lintas Pada Jalan Tol Purbaleunyi, Jurnal Teknik Sipil, Bandung.

5. Anwar, 2015, Pemetaan Risiko (Risk Mapping) Keselamatam dan Kesehatan Kerja Pada Area Laboratorium Kimia PT.PJB UBJ O\&M PLTU Paiton 9 Kabupaten Probolinggo, Skripsi, Jember.

6. Austroads, 2002, Guide to Road Safety Part 6: Road Safety Audit. Australia: Author.

7. Departemen Perhubungan, 2006, Penyusunan Rencana Umum Keselamatan Transportasi Darat, Jakarta, Departemen Perhubungan.

8. Ramli, dkk, 2010, Sistem Manajemen Keselamatan \& Kesehatan Kerja, Skripsi, Jakarta.

9. Wiryani, dkk, 2013, Pemetaan Risiko di Industri Penyamakan Kulit Dengan Pendekatan Enterprise Risk Management (ERM), Jurnal Manajemen, Bogor.

10. Wiranto, dkk, 2014, Evaluasi Tingkat Kerawanan Kecelakaan Pada Ruas Jalan Boyolali-Ampel KM 29+000-34+000, Jurnal Matriks Teknik Sipil, Universitas Sebelas Maret, Surakarta.

11. Pamungkas, dkk, 2017, Analisis Lokasi Rawan Kecelakaan di Jalan Arteri Primer Kota Surakarta, Jurnal Matriks Teknik Sipil, Universitas Sebelas Maret, Surakarta. 
12. Ardianto, 2011, Metodologi Penelitian untuk Public Relations Kuantitatif dan Kualitatif, Simbiosa Rekatama Media, Bandung.

13. Creswell, 2010, Research Design, Pendekatan Kualitatif, Kuantitatif dan Mixed, Pustaka Pelajar, Yogyakarta. 